Abstracta Iranica Abstracta Iranica

Revue bibliographique pour le domaine irano-aryen

Volume 26 | 2005

Comptes rendus des publications de 2003

Traces d'eaux: un géographe chez les archéologues. Paris, Belin, 2003, 224 p., ill. en coul., cartes. (Asie plurielle).

Bernard Hourcade

(2) OpenEdition

Journals

Édition électronique

URL : http://journals.openedition.org/abstractairanica/991

ISSN : 1961-960X

Éditeur :

CNRS (UMR 7528 Mondes iraniens et indiens), Éditions de l'IFRI

Édition imprimée

Date de publication : 15 mai 2005

ISSN : 0240-8910

Référence électronique

Bernard Hourcade, «Traces d'eaux : un géographe chez les archéologues. Paris, Belin, 2003, 224 p., ill. en coul., cartes. (Asie plurielle). », Abstracta Iranica [En ligne], Volume 26 | 2005, document 449, mis en ligne le 15 décembre 2005, consulté le 25 septembre 2020. URL : http://journals.openedition.org/ abstractairanica/991

Ce document a été généré automatiquement le 25 septembre 2020.

Tous droits réservés 


\section{Traces d'eaux: un géographe chez les archéologues. Paris, Belin, 2003, 224 p., ill. en coul., cartes. (Asie plurielle).}

\section{Bernard Hourcade}

L'analyse géographique, par un géographe, des données archéologiques sur l'occupation du sol, les canaux d'irrigation a été initiée par l'A. à la fin des années 1960 notamment dans le nord de l'Afghanistan. Cet ouvrage fondé sur des sources très spécialisées, mais rédigé pour un public savant mais non spécialiste, démontre, à partir d'exemples multiples pris surtout en Asie centrale et Afghanistan, combien le regard et les méthodes de la géographie peuvent apporter à l'histoire sociale et économique de civilisations dont on ne retient souvent que les dimensions artistiques, politiques ou religieuses.

\section{INDEX}

Thèmes : 15.1. Iran

Mots-clés : canaux d'irrigation

Keywords : irrigation canals 
AUTEURS

BERNARD HOURCADE

CNRS - Paris 